\title{
The Ongoing Story: A process with a product for classes in spoken English
}

Jean Black

In recent years, the emphasis in composition classes in the second language classroom has been placed on the process of writing rather than on the product. The rationale behind this methodology is to move students from a paralyzing fixation on the blank page upon which no errors must occur to a discovery of the rewriting process by which meaning and form are gradually refined. Classes in speaking often founder on the shoals of the opposite problem: they are all process with no product. Students do what they are supposed to do-speak-but, aside from their recorded and graded presentations, they have nothing concrete to show for their efforts at the end of this process, and they sometimes wonder what they have accomplished.

The story-telling process I describe here solves this problem and has a number of other advantages. It uses an interactive approach to story telling, yet it gives students an end product (the story) to read, criticize, laugh at, and take home-without their having to write a single word. While it is ungraded and non-threatening, it does require some discussion and thoughtful decisions.

Essentially, the ongoing story is told by all the students over the term. The teacher acts as instigator, arbiter, scribe, and typist. I have used this activity in Spoken English classes composed of young adults at an advanced-beginner or low-intermediate level (Level 2 of a five-level intensive programme), but it would also be appropriate at more advanced levels of proficiency. No special materials are required for the students. The teacher's task, however, will be facilitated by access to a computer since the teacher/scribe types up each episode from notes taken in class and incorporates into the story any changes that students demand along the way.

\section{Procedure}

I used this activity for part of a period, one day a week of a 14-week term. (It could last from 15 to 30 minutes depending on the time allowed by the teacher and the enthusiasm of the students.) We did not begin the story until several weeks had elapsed in order to give the students time to feel comfortable with each other and with the teacher. Also, the students then had more vocabulary and functions at their disposal when it came to 
telling the story. The course I was teaching was organized around thematic units and related functions. In the transcripts of the stories, one can see these themes of travel, family, physical and psychological characteristics, health, food, entertainment, and careers emerging along with functions such as describing, comparing, contrasting, and inviting.

In telling the story over the term, we worked first as a class, then in small groups, and finally as individuals. The rationale was to move from a secure situation to a risky one at a pace that the students could accommodate.

\section{Getting started as a class}

For the story "François and Sherry". (See the Appendix for the transcript; I chose this story for inclusion here because it was the shortest, not the best.) I began the process by giving the class the two main characters and the setting; that is, I began by saying that we have two students-a young man and a young woman-at our home university. As a class, we decided on the physical appearance of Sherry and François, their personalities, and where they came from. This was done by my eliciting responses to questions such as, "What colour hair does Sherry have? What kind of person is François?" Disagreements arose, which we settled by discussion or, when that failed, voting.

\section{Taking notes}

As the students compiled their descriptions, I took brief notes of what was decided and after each episode typed these onto computer disc. I did this so that we would always have an ongoing version of the story for reference and so that at the end we would each have a copy of the complete version. Also, I took on the role of scribe myself because I wanted the experience for the students to be primarily an oral/aural one during the creating and communicating stage.

A word of caution is in order here. The notes should be taken quickly and unobtrusively. If the scribe tries to write down everything exactly as the students say it, the whole process will become a dictation exercise for the teacher rather than a speaking exercise for the students. Because I told the students I was taking brief notes only, I felt no compunction, when typing the episodes, about correcting grammar mistakes or at times using sentence structures more sophisticated than the ones they had actually spoken in class. For the most part, I reproduced the original diction as closely as grammaticality and the brevity of my notes allowed, but the advantage of this ghostwriter approach is that it helps students go beyond the boundaries of their various interlanguages. We also decided to use the present tense both in the telling and the writing because it conveyed the 
immediacy of the ongoing nature of the story. (Besides, I wanted the students to practice the problematic third person singular!)

\section{Working in groups}

After a session or two of class decisions, we were ready to move on to group work. For this I divided the class into small groups of about four students each, and assigned each a task: for example, to make up the family background of one of the characters, or to explain why the students were at the university, or to describe their families and friends. During this process, I circulated among groups, helping out where necessary. As with any group work, it proved advisable to set a time limit. When all groups finished, I returned to my role of scribe, and the various groups reported their decisions to the whole class.

\section{Working as individuals}

At this point in the story-telling, it was obvious that a different approach had to be taken. While concurrent groups worked well for the early descriptive parts of the story, they would not work for the sequential portions in which one episode had to grow out of another. I decided that the students had enough confidence now to work in a more independent fashion. Several days before the next story-telling session, I chose three students and told them that they would tell the next episode, each one contributing a small part. Ideally, these students should not share an L1, or at least the middle student should have a different L1 from the other two. They were to prepare their three-part episode sequentially and outside of class. They could contact each other in person, or they could telephone each other. That is, the first student would contact the second and relate the first bit of the episode; the second student would then contact the third to relay the second portion, and the third student would save the last portion for the class. (We had worked on telephoning in one of the core units of the course.) The three were also free to get together to discuss their entire episode if they wanted to take joint responsibility for it. When they came to class on story-telling day, they told the three parts of the story one at a time in sequence to the class and to the teacher, who, as usual, acted as scribe. Again, the rest of the class listened, asked for clarification, raised objections or made suggestions. At any stage of the story, students could ask the teacher for a printout in order to refresh their memories about details.

This three-student process continued until everyone in the class had made an individual contribution. When naming the students, it is wise to save someone fairly proficient and imaginative for the end so that, if necessary, the story might be retrieved from a dead end or given a concluding fillip. 
A word of caution is necessary here. When the students are making their individual contributions, they should not simply read chunks that they have written beforehand. If absolutely necessary, they can use very brief notes to help them remember, but they should tell the story not read it.

\section{Enjoying the product}

When the story was finished, I added the last episode to the disc, and circulated copies of the whole story to the class. We read it aloud, and discussed any linguistic problems. This also provided the students with another opportunity to remark on loose ends, interesting bits of characterization, the general tone sentimental or violent, for example), or purple passages. When the students confronted the printed story, they were generally astonished by the sea-change their efforts had undergone. They marvelled at how much they had created and how good their story sounded on paper.

\section{Conclusion}

The ongoing story technique has a number of practical advantages: 1) It can be used at any proficiency level beyond the beginner stage; 2) It can be adapted to various class sizes and term lengths; 3) It requires no special materials for the students.

More importantly, it is pedagogically sound: 1) It is truly interactive in that the students have to listen and speak to each other in order to advance the story; 2) It gives the students time to develop confidence in groups before requiring them to perform individually; 3 ) It allows the students to draw on what they have learned in the rest of the course while encouraging them to reach beyond that to other language items and structures they need to tell the story; 4) The activity is almost completely process-oriented, but the ghostwriting technique provides the students with a product which they have created but have not had to write. This version could be included in a student newspaper or given to a reading class; 5) The ghostwriting technique serves as a tactful method of error correction. The story tellers recognize their ideas on the page, couched in grammatical forms that they were struggling, not always successfully, to generate themselves.

\section{APPENDIX}

\section{Transcript: "Sherry and François"}

Sherry Wilson is an attractive 20-year old. She has long, wavy blond hair and big blue eyes. She is average in height and slender. She keeps in shape by swimming and playing tennis, and she also enjoys gymnastics and aerobics. 
Sherry's home is in St. Catharines. She has a younger sister called Sylvia and an older brother called Bob. Her parents are loving and caring people. Friends also play an important part in Sherry's life because she has an outgoing personality. Two of her closest friends are Michelle and Anastasia.

Sherry is attending Brock University, where she is studying economics.

François Bouvier is from Geneva, Switzerland. He is 22 years old and striking in appearance: clean-shaven, tall and slim with straight black hair and brown eyes. François looks athletic and he is. He swims, skis, and plays tennis and polo.

An only child, François is a sensitive person. He is quite shy, and likes to spend some time by himself. His father died when he was only ten years old. His mother, who was born in West Germany, is a pianist.

François is now studying in Level 3 of the Intensive English Language Program at Brock University. In Geneva, he had completed his degree at university, where, like Sherry, he was studying economics. However, he decided that before continuing with his studies, he should take a year off to improve his English. He chose to come to Brock because he has a friend who is already at Brock.

François lives with a Canadian family on Glendale Avenue. Mr. and Mrs. Baker have three married children-two sons and a daughter, who no longer live with their parents. François is very happy with the Bakers.

One day a few weeks after the beginning of the term at Brock, François goes to the cafeteria to have lunch. The room is very crowded, and all the tables are occupied. François stops beside the table where Sherry is sitting.

"May I sit down?" he asks.

"Of course," she replies.

Noticing that he has a French accent, Sherry asks François where he is from. Soon they are deep in conversation.

"Do you usually have lunch here?" Sherry wonders.

"On nice days I eat outside, but sometimes here too," he tells her. "What meals are the best?"

"Pizza or soup," Sherry informs him.

"Next time," François says, "I'll try that. My turkey sandwich is only so-so."

The two keep bumping into each other. The next day they meet accidentally in the lobby and again in the cafeteria. Soon they become good friends. Their meetings are no longer accidental, but planned.

A few weeks later François and Sherry discuss what they are going to do during the Christmas vacation. François wants to go skiing in Quebec, but Sherry thinks that they should both go to Switzerland. They have their first quarrel. Finally François convinces Sherry that it is important for him to stay in Canada and speak English. He suggests that Sherry visit him and his mother in Switzerland during the following summer vacation. She can fly to Geneva, and they will pick her up and take her sightseeing. She agrees to this plan.

In the meantime, François and Sherry are enjoying life in St. Catharines. Both of them are athletic. One day they meet briefly between classes and make arrangements to go ice skating after class. 
"See you later," François calls happily over his shoulder.

"See you," Sherry shouts back, as they each go their separate ways.

At the skating rink, François and Sherry meet at the entrance. They put on their skates and for awhile enjoy skating. Suddenly, a little girl crosses in front of Sherry. Sherry cannot dodge very well, and tumbles to the ice.

"Are you all right?" François asks in alarm.

Sherry is embarrassed, but she thanks François for helping her up.

"Let's stop skating," François suggests.

They go to the Pen Centre to have ice cream. When they part, they promise to meet each other after class the next day in the lobby, as usual.

When they meet the following day, Sherry invites François to go skiing with her on the week-end at Holiday Valley in New York state. François says that he would love to go.

The next Saturday they set out early in the morning. When they arrive, François rents a pair of skis and gets a free lift pass for $\$ 25$, which he considers to be a very good rate Sherry cannot wedel so she asks François to teach her. While she is trying to follow him, she flips and breaks a leg. She is taken to the hospital in Buffalo. Her leg is set, and she has to spend a few days there. When she returns home to St. Catharines, François goes to her house daily and helps her to walk. Finally, after six weeks the cast is removed. Now François and Sherry are even closer friends.

It is the Christmas season. Sherry invites François to spend the holiday with her family. He goes with the Wilsons into the country to cut down a Christmas tree, and they have a great deal of fun. At home they decorate the tree and put gifts under it. On Christmas day Sherry gives François some new skis, which please him very much. François gives Sherry an engagement ring, which pleases her even more. It is a beautiful diamond with a platinum band. Sherry, who is very excited by the gift, accepts François' ring and his marriage proposal. Her parents and Bob and Sylvia are also delighted with the idea of having François join the family.

They plan to marry a year from now, in January, when François will have finished his English studies. When they telephone his mother to tell her the news, they are surprised to learn that she has been arranging to move to Canada. Because Sherry and François are both bilingual, they could live in either Canada or Switzerland. They decide to settle in St. Catharines. When François finishes the IELP, he will get a job, and Sherry will finish her degree at Brock. Then they will get married, honeymoon in Switzerland, and live happily ever after.

\section{THE AUTHOR}

Jean Black has an MA in English and a BEd in TESL. She has taught English at the University of Saskatchewan and Niagara College. Since 1986 she has been teaching ESL in the Department of Applied Language Studies at Brock University. She has also taught ESL at the University of Essex, where she worked as an exchange teacher in the summer of 1988 . Her teaching focus is on oral/aural skills. 